\title{
The Impact of Refugees on Conflicts in Africa
}

\author{
Grace Atim \\ Institute for Peace and Conflict Resolution Abuja
}

\begin{abstract}
This paper seeks to investigate the impact of refugees on conflict in Africa and in the process posits that a refugee is someone who has been forced to flee his or her country because of persecution, war, or violence. A refuge has a well founded fear of persecution for reasons of race, religion, nationality, political opinion or membership in a particular social group. Most likely, they cannot return home or are afraid to do so. War and ethnic, tribal and religious violence are leading causes refugees fleeing their countries-may trigger conflicts between sending and receiving states. This paper asset that both refugee-sending states and refugeereceiving states are more likely to initiate militarized disputes against the other. More generally, it contributes to a broader research agenda which examine the mutually reinforcing relationship between conflict within and between states. Often, the issues and actors in civil wars span national boundaries and become part of a regional security dynamic, blurring firm distinctions between domestic and international politics. Other challenges of refugee including culture shock, crime and criminality as well as health challenges emanating from refugee are also looked at.
\end{abstract}

Key Words: Refugees, Conflict, Security, Host country,Border, War, Asylum, Spill-over effect, Migration, Communities.

\section{Introduction}

The problem of human displacement in Africa is large and possibly growing in scale. A great deal of qualitative evidence suggests that the situation of Africa's displaced people is becoming increasingly problematic and that those who succeed in escaping from their country are unable to find a safe refugee in other states.

With the increase in armed conflicts in Africa and the West Africa Sub-Region there exist various dimensions of environmental, social and security challenges posed by refugee influx into most countries of Africa. This paper therefore, seeks to examine the dynamics of the socio-Political and economic implications that are associated with refugees' security phenomenon, within the African continent. The broad objective of this study is to find out the problems associated with refugees in the host country, while the specific objectives of the study is to unravel the implication of refugee on Africa's social, political, security and economic development. The study it is hoped would serve as an early warning indicator to government in its drive at maintaining peace and security of the country's internal and border securities. The paper has provided a conceptual clarification of some of the concepts, historical background of conflicts in Africa, the effects of refugees on host countries, as well as provided a survey of African Refugee experience. The paper has also provided a conclusion and recommended the establishment of mechanisms of resolving disputes between individuals and groups of people and building where possible on the social and legal traditions of the refugee population among others.

\section{Conceptual Clarification}

The 1951 United Nations Convention on the Status of Refugee, defines a refugee as person "who owing to a well founded fear of being persecuted for reason of race, religion, nationality, membership of a particular social group or political opinion and that such a person is outside the country of his nationality and is unable or owing to such fear, unwilling to avail himself of the protection of the country". Regional instruments in refugees expanded the UN definition. For example, the convention governing the specific aspect of refugees problems in Africa, a relational instrument adopted by the organization of Africa Unity (O.A.U) now AU in 1969, besides adopting the UN definition expanded it to include; people fleeing from external aggression, internal civil strife, or events seriously disturbing public order in African countries. The definition of who a refugee therefore may vary in scope although the $1951 \mathrm{UN}$ Convention definition is normally taken as the standard for "genuine" refugee status. Before a refugee acquires refugee status in the country they have fled to, they are normally called asylum seekers. After their request has been considered genuine they are registered and given the refugee status. This is when they are now officially handed over to UNHCR as mandate refugees. (UNHCR) 2010). 


\section{Historical Background Of Conflicts And Refugees In Africa}

The magnitude of refugee influx in African countries in recent years has generated concern throughout the world. Widely perceived as an unprecedented crisis, these flows have produced a mixture of humanitarian concern of the millions of people forced into exile and fear for the potential threat to the social, economic and political stability of host states caused by streams of unwanted newcomers. Africa continues to produce a disproportionate number of the world's refugees in relation to its overall population; thus, in 1994, around 47 percent of the refugees recorded by UNHCR were to be found in Africa. By 1998, the proportion had dropped significantly, to its current level of 28 per cent. In absolute terms, the number of refugees in Africa fell by more than 50 per cent in the same period: from 6.75 million in 1994 to 3.2 million in 1998 (Crisp 2000). The host states are therefore struggling to strike a proper balance between the need to maintain control over their borders and the need to protect refugees who seek asylum within their borders. According to Albert (2012) Social conflict is the most central subject-matter of history. For example, issues relating to the founding/collapse of kingdoms or empires; migration of peoples resulting from natural or man-made factors; colonialism, racism, ethnocentrism, wars and peace all border on social conflict. So also are issues of pleasure and pain, wealth and power; modernity and history; gender relations; suppression, resistance and violence; and local versus global process. In other words, the world is in a state of constant flux and this is conditioned by social conflict. History has indicated that a peaceful and prosperous world is one which people are safe and secure in their home with their families. It is a world in which people expectedly feel confident in their country their culture and in the family of nation and people in the world. Furthermore, for economics or others personal reason, people can decided to relocated and abandon their home to new location to begin new life. This, often can be in search of pastures, but when nature intervenes in the form of natural disaster people's home are washed away, blown way, or shaken to the ground or, the ground, uprooting entire community like it was the case in several states like Benue,Kogi,Taraba and Plateau in Nigerian 2012. Also, when war or civil unrest ravages a community masses are forcibly displaced.

According to Albert (2012), Historical facts buttress that a peaceful and prosperous world is one in which people are safe and secure in their homes with their families and in their communities. It is a world in which people expectedly feel confident in their country, their culture and in the family of nations and people in the world. Further, for economic or other personal reasons, people can decide to relocate and abandon their homes to new locations to begin new life. This often can be in search of greener pastures.

But when nature intervenes in the form of natural disasters people's homes are washed away, blown away, or shaken to the ground, uprooting entire communities like it was the case in several states such as Benue, Plateau,Nassarawa and Kogi in Nigeria in 2012. Also, when war or civil unrest ravages a community masses are forcibly displaced or simply flee to protect life and property. At the extreme, they are left with only two options: death by deprivation, assault or genocide, or life in exile. One need only think of those forced to flee the violence in several nations in Africa and also where to have a glimpse of the severity of their need as displaced people. Such events and times generate population dislocations and mass refugee migration across national boundaries. Civil wars in Sudan, Liberia and Mali, to name a few examples, have significant repercussions for states in Africa as people leave their homes in search of safety elsewhere.

Government persecution of political opponents, human rights violations, and ethnic cleansing campaigns normally understood as matters of domestic politics may also have far reaching effects as migrants flee one sided violence by their government. These refugee flows can be quite large; conflicts in Sudan, Mozambique, and Rwanda have generated well over one million refugees each. Therefore, political turmoil at the domestic level can have significant spillover effects for other states and may provoke strong reactions by others when external costs are high. In addition, internal violence may extend across national boundaries as conflicts between government and refugees or dissidents are frequently not contained by borders.

\section{African States And Refugee Conflict Dynamics}

Gil Loescher (1996) stresses on the need to not only see refugees as a humanitarian problem but also as a political problem particularly in terms of security. He argues that: too often refugees are perceived as a matter for international charity organizations, and not as a political and security problem, yet refugee problems are in fact intensely political. The presence of refugees accelerates existing internal conflicts in the host countries.

During the 1980's for example, exiled populations constituted threat to social stability and political security within the African continent. At the local level, refugees are frequently (and not always unfairly) associated with problems such as crime, banditry, prostitution, alcoholism and drugs. In many instances, host countries simply do not have the capacity or willingness to maintain law and order in the remote and underdeveloped areas where the largest number of refugees are often to be found (Crisp 2000).

The relatively liberal refugee policies by the states of Africa during the first 20 years of independence have often been attributed to the continent's "tradition of hospitality". While this factor should not be entirely discounted, it is important to recognize the extent to which the principle and practice of asylum was 
underpinned by other considerations in the period under discussion. From the early 1960's until late 1970's,many Africa's refugees were the product of independence struggles and wars of national liberation, most notably in countries such as Angola, Ginea-Bissau,Mozambique,Rhodesia,South Africa and South West Africa.

The ideologies of pan African and anti-colonialism remain strong throughout much of the continent and influential political leaders such as Julius Nyerere and Kenneth Kaunda set a positive example in the refugee policies which they pursued. At the same time, the relative prosperity of many African states in the early years of independence and the modest size of the refugee movements which took place at this time enabled those countries to shoulder the economic burden imposed by the presence of refugees from neighbouring and nearby states.

\section{The Effects Of Refugees On Host Countries}

Several authors have asserted that refugees tend to impact adversely on the safety of various nation states. Recent work confirms the intuition that political violence and persecution are significant determinants of flight (see e.g. Davenport, Moore, Poe 2003; Melander and Oberg 2006; Moore and Shellman 2004). Yet, refugees are not simply the unfortunate by-products of war, but may serve as catalysts for conflicts, including conflict between states. Scholars have suggested that refugee migration can provoke international hostilities between states, including military action (Dowty and Loescher 1996; Posen 1996), although this claim has not been rigorously tested. For instance, it is argued that Rwanda invasion of Zaire in 1996 was largely motivated by the desire to clear refugee camps that harbored militant factions.

Refugee crises do not only bring about humanitarian disasters but also create serious implications for Border States and host communities. According to Bobbin, and Garrett (2006), the terms internal or domestic and civil conflict imply violent interactions between states and dissidents, and the negative consequences of war and human rights violations, contained within the states. Rather than treating states as independent units, it may be more appropriate to view them interconnected in dense networks of social interactions where process within one state have significant repercussions for other states in the region and elsewhere. The human costs of civil war and state persecution may not be entirely borne by the warring country only, but may create significant externalities, or spillover effects, for other countries/communities.

The problems associated with refugees may not be restricted to a particular border area but may have spillover effects on the internal security situation of a region. As posited by Martin (2005), refugee migration can inflict a significant economic burden on host countries or communities. This may be so not minding the availability of international aid, which at time may be from the world's poorest nation who may often bear much of the cost of maintaining them. Refugees require humanitarian assistance and public service supplied by their hosts, and may compete with locals for jobs and scarce resources, bringing them into conflict with domestic actors. In the same line, Cortes (2004), has said that compared to voluntary labour migrants, refugees are also less likely to contribute to productive economic activity in their hosts. This sterns from the fact that unlike economic migrants, refugees are not selected for their skills, may have suffered war trauma making employment difficult, and may have lost their assets prior to fight. In a related study, Murdoch and Sangler (2004) have revealed that civil wars in one country have a significant negative impact on GDP growth in neighboring states; they propose population migration as a potential causal factor, but do not test this explicitly.

Also, refugees can be a source of negative public health with adverse consequences for their host countries. Refugees camps are often crowded and unsanitary, creating conditions ripe for infectious diseases; refugee inflows stretch domestic medical resource thin; divert health resource away from normal care; and refugees may have specific health needs related to war trauma that overwhelm the host. To that effect, Ghobarah, Huth, and Russet (2003) and Igbal, (2006) in different research works revealed that civil wars significantly increase the rate of morbidity and mortality in the affected country itself as well as in neighboring states. In the same line separate studies have also shown that refugees have contributed to the spread of diseases such as HIV/AIDS, Malaria, and diarrhea, among other infectious diseases (Collier et al 2003; Rowland and Noosten 2000; Toole and Waldman 1997).Further, Wiener $(1992 ; 1978)$ assets that refugees may upset the ethnic balance in their host countries through what may be thought of as a demographic externality. Refugees and immigrants may be seen as unwelcome foreigners and cultural 'threat' to the host community. Ethnic tensions may become especially pronounced when refugees possess ethnic ties with groups already present in the host society. In countries where ethnic cleavages are deeply entrenched, large, unexpected migrant inflows may tilt the delicate ethnic balance in the host society and spark inter-group conflict Brown, (1996) further attests that, "The sudden influx of refugees can aggravate ethnic problems and further complicate the picture by changing the domestic balance of power. "Lake and Rothschild (1998) point to similar dynamics in their discussion of the diffusion of ethnic conflict across state.

Finally, refugee's flows may directly affect the security and stability of the host country by contributing to organized armed conflict on the territory. Salehyan and Gleditsch (2006) have observed that refugee's inflows from neighboring states significantly increase the risk of civil war. Along with the refugees themselves, foreign 
fighters, arms, and ideologies that contribute to violence may also stream across the border, 'refugees warrior' communities as asserted by various scholars (including Lischer (2005); Salehyan (2007); Zolberg, Suhrike, and Aguayo (1989)) can expand rebel networks to encompass the host state when militants established bases on external territory and can form social ties with domestic opposition groups with a similar ethnic or political orientation. Therefore, at the extreme, refugee inflows may lead to violent turmoil on the host country's territory.

According to Andreas (2003); Herbst (1989); Jackson (1987); Zacher (2001), in the cases of refugee migrant, such flows threaten to extend violence and opposition activities across national boundaries. Migrants flee civil war and state persecution for safety in countries of asylum, and most of the world's refugees flee to countries in close proximity to their country of origin. However, particularly when borders are porous, they are necessarily immune from continued attacks by the state. States may pursue their ethnic and or political rivals across the border, and such attacks necessarily violate the sovereignty and territorial integrity of others. States could object military incursions on their soil, particularly if local populations also become caught up in crossborder attacks. No state welcomes foreign incursions and military violations of their sovereignty, even though the physical ability to firmly control border may be lacking.

Of interest is the fact that refugees may not be passive actors, however, in many cases, while the vast majority of refugees never directly participate in violence rather than being unfortunate victims of violence, some refugees have mobilized into insurgent organizations and refugee camps often serve a double-purpose as sanctuaries for militant groups (Lischer 2005, Salehyan 2007a; Stedman and Tanner 2003; Zolberg, Suhrke, and Aguayo 1989). Recruitment into a rebel organization may provide refugees a better alternative to life in a camp and provide individuals a sense of purpose. These 'refugee warrior' communities sometimes form when their hosts are too weak to prevent the militarization of refugee camps; in other cases, host countries actively encourage and aid dissident activities as a way to undermine their international rivals. Thus, violence between the countries of origin and refugee communities may not be one-sided, but takes the form of transcontinental civil wars that span intercontinental boundaries (Salehyan 2007a; 2007b). Indeed, Gates (2002) argues that the sub-national level on the geography of civil conflict have confirmed that battles frequently take place in close proximity to international borders and refugee warrior groups are likely to be responsible for much of this find.

Offending states may launch attacks on their neighbour's territory in order to strike at external rebel bases and to clear refugee camp close to the border.

As asserted by Bapat (2006), Salehyan (2007), and Schuktz (2007), bargaining and negotiations, may be difficult in these circumstances. Cross-border strikes against external rebel bases and 'hot pursuit' raids may jeopardize bilateral relations, but the costs of confrontation with the host state may be seen as acceptable when compared with the tactical advantages to be gained over domestic rebel organizations. Moreover, disputes about alleged host country support for rebel organization are difficult to resolve through bargaining because it may be difficult for the host state to credibly commit to reversing its policies. In many instances host countries deny supporting rebels despite home country allegation, and it is difficult to prove that the state is not engaging in a pernicious policy; it is hard to prove a negative fact. Verifying compliance with demands to discontinue rebels support is difficult since rebel assistance may continue covertly. Moreover, state supporting rebel organizations may find that the benefits of promoting instability in neighbours outweigh the risk of retaliatory strikes. Finally, refugee host state may find it difficult to comply with demands to evict rebel organizations because they find it too costly and dangerous to forcibly move against such groups.

\section{A Survey Of African Refugee Experience}

Economic conditions such as strong dependency upon a primary commodity or slow economic growth can instigate conflict between communities and create a refugee crisis. For instance in Sudan, access to and control over natural resources, oil, water and human labour have been a key factor for actors on all levels to continue being involved in violent conflict.

This discussion suggests that refugee origin states may launch militarized dispute against refugee host states. Such dynamics have been recently apparent during the refugee crisis in Darfur and Syria/Turkey border.

Refugees from the Sudanese Region of Darfur have fled to Eastern Chad and have been attacked by government forces alongside their paramilitary allies seeking to eliminate ethno-political rivals. Also, Liscer (2005) asserts that the Rwandan genocide in 1994 shocked the world for it's level of brutality, but beyond the immediate human toll, it contribute to long-term instability across the great lakes region of Africa. The Arusha accords signed between the Tutsi-dominated Rwandan Patriotic Front (RPF) and the Hutu-led government was viewed by some members of the Hutu elite as granting too much power to the RPF. Yet, before the accords could be implemented, Rwandan President Juvenile Habyarimana was assassinated, providing the excuse Hutu extremists needed to begin a campaign of genocidal violence against Tutsis and moderate Hutus. To put an end to the genocide, the RPF re-invaded the country from their bases in Uganda and toppled the government in Kigali, which in turn prompted an enormous refugee exodus as millions of Hutus fled the country. 
Fearing RPF reprisals, this mass emigration was encouraged and orchestrated by the ex-Rwandan Armed forces (ex-FAR) and the Interahamwe militias, who sought to establish a government-in-exile and regroup as a rebel force across the border. At the peak of the refugee crisis, Zaire and Tanzania hosted over one million Rwandan refugees each. Yet, as Lischer (2005) explains, while Tanzania took steps to prevent refugee militarization, Zaire's President Mobutu Sese encouraged its spread. Seko was neither willing nor able to prevent the ex-FAR force from taking control of the camps. This posed an enormous humanitarian dilemma for aid agencies as the necessity of feeding and sheltering legitimate refugees was complicated by the fact that the camps were largely run by the perpetrators of the genocide (Gourevitch 1998; United Nations High Commissioner for Refugees 200). Officials on the ground understood the gravity of the situation. Shahyar Khan, the UN Secretary General's representative to Rwandan exclaimed, "we are sitting on a volcano....we must separate the wolves from the sheep".

From inside Zaire, the ex-FAR Interahamwe force began to mobilize militarily, while gathering recruits and supplies among the refugees. News reports estimated that roughly 40,000 fighters were present in and around the Zairean town of Goma. Clashes between Hutus and local Zairean Tutsis ensued with the complicity and supports of President Mobutu, whose force were responsible for their own human rights violations against Tutsis. From Rwandan, the RPF leader (and later Rwandan's President) Paul Kagame viewed the refugee situation in Earthen Zaire with alarm. As the international community was unwilling to devitalize the camps, Rwandan decided to act on its own. As Kagame would relate in an interview as Quoted in Gourevitch (1998)."We were ready to hit them... and handle three things: first to leave the Banyamulenge (Zairean Tutsis) and not let them die... then to dismantle the camps, return to refugees to Rwandan, and destroy the ex-FAR and militias; and third, to change the situation in Zaire".

\section{Conclusion}

The paper was set to establish the impact of refugees on host countries. Refugees do not only create humanitarian disasters but often times create implication and spill over effects for Border States and host communities.

Refugee can serve as catalysts for conflicts within the host community; there is also the economic burden on host community, because refugee requires humanitarian assistance.

The paper has also, found that refugee create negative public health with adverse consequences for the host country. Refugees most times pose a security threat to the host country. Refugee influx affects the development of women and children in host countries.

\section{Recommendations}

For peace and stability to be achieved and sustained there is the need for nations to give purposeful leadership by providing adequate security of lives and property, and good governance. Serious attention should be paid to early warning indicators, and mechanisms be put in place for early response to conflicts to avoid spill - over effect and refugee influx of countries must always focus and adhere on upholding principles, then international law and strengthening border security of their countries.

Apart from the regular immigration and custom posts at border stations, host countries could create military brigades at strategic post to check the influx of refugees into host countries. This would prevent spill over effects on the host country.

Extra provision of infrastructure and other joint venture that could gainfully engage nationals of border countries should be encourage minimizing the influx of people into the heartland of neigbouring countries.

Intelligent information gathering and sharing among border countries should be encouraged to avoid the escalation of internal conflicts into the neigbouring states.

The extent to which law and order is upheld in refugee camps might also be enhanced by means of efforts to inform refugees of their obligations under international and national law. In this respect, it is worth recalling the article of the UN Refugee Convention which states "every refugee has duties to the country in which he finds himself, which he finds himself, which require in particular that he conform to its laws and regulations as well as to measures taken for maintenance of public order".(UN 1995). Education and Information programmes might be established to convey this message to refugee populations and to warn them of the consequences of non-compliance.

Additional efforts could be made to limit to the level of tension and conflict that inevitably exists in refugee camps. The establishments of mechanisms to resolve disputes between individuals and groups of people should be encouraged, building where possible on the social and legal traditions of the refugee population, and again recognizing the special role which women can play in this respect. Educational, cultural and sporting activities could be encouraged, targeted particularly at those adolescent males who are most likely to become involved in destabilizing criminal, political or military activities. 
Vocational training and income-generating programmes could also be established, thereby improving the quality of life experienced by refugees and providing them with some hope for the future. Above all, perhaps, Africa's refugees should again be given access to land and agricultural opportunities, as they usually were in the 1960s and 1970s rather than being confined to camps for years on end without any prospect of becoming self-sufficient.

\section{References}

[1]. Albert, I. O. (2012): Mapping the Discourse; History Social conflict and Conflict Management (Ed) Albert I. O.; A history of Social Conflict and Conflict Management in Nigeria, Ibadan, Peace and Conflict Studies Programme.

[2]. Andreas, Peter (2003); Redrawing the Line: Borders and Security in the Twenty First Century, International Security 28 (2):78-1 11.

[3]. Article 2 of the $1951 \mathrm{UN}$ Convention relating to the status of Refugees.

[4]. Bapat, Navin (2006); State Bargaining with Transnational Terrorist Groups. International Studies Quarterly, 50(1):213-230

[5]. Clark, John F. (2004) The African Stakes of the Congo War, (ed) New York:

[6]. Palgrave Macmillan, Collier, Paul and Anke Hoeffler (2004) Greed and Grievance in Civil War. Oxford Economic Papers, 54(4):563-595.

[7]. Cortes, Kalena (2004); Are Refugees different from Economic Immigrant? Some Empirical Evidence on the Heterogeneity of Immigrant Groups in the United States. Review of Economics and Statistics. 86(2): 465-480.

[8]. Crisp, Jeff (2000) New issues in Refugee Research. Africa's Refugee: Patterns, Problems and Policy Challenges: Working Paper No.28 UNHCR CH.IZ1, Geneva.

[9]. Davenport, Christian, Will H. Moore and Stephen Poe (2003);

[10]. Sometimes you just have to leave: Domestic Threats and Forced Migration, 1964-1989. International Interactions 29(1):27-55.

[11]. Dowt, Alan and gil Loescher (1996); Refugee Flows as Grounds for International Action. International Security. 21(1):43-71.

[12]. Ghobarah, Hazem, Paul Huth, and Bruce Russett (2003) Civil Wars Kill and Maim People.

[13]. Martin, Adrian (2005); Environmental Conflict between Refugee and Host Communities. Journal of Peace Research. 42(3):329346.

[14]. Melander, Erik and Magnus Oberg (2006); Time to Go? Duration Dependence in Forced Migration. International Interactions. 32(2):129-152.

[15]. Moore, Will H. and Stephen Shellman (2004); Fear of Persecution:

[16]. Forced Migration 1952 - 1995 Journal of Conflict Resolution. 48(5):723-745

[17]. Murdoch, James and Todd Sandler (2004); Civil Wars and Economic Growth: Spatial.

[18]. Posen, Barry (1996); Military Responses to Refugee Disasters. International Security. 21(1):72-111.

[19]. Rowland, M and F Nosten (2001); Malaria Epidemiology and Control in Refugee Camps and Complex Emergencies. Annals of Tropical Medicine and Parasitology. 95(8):741-754.

[20]. Salehyan, Idean and Kristian S. Gleditsch (2006); Refugees and the Spread of Civil War, International Organization. 60(2):335-366.

[21]. Salehyan, Idean (2008); No Shelter Here: Rebel Sanctuaries and International Conflict, Journal of Politics, forthcoming

[22]. Toole, MJ and RJ Waldman (1997); The Public Health Aspects of Complex Emergencies and Refugee Situations. Annual Review of Public Health. 18(1):283-3, 12.

[23]. United Nations High Commissioner for Refugees (2000); The State of the World's Refugees, Fifty Years of Humanitarian Action. New York: Oxford University Press. Long after the Shooting Stops. American Political Science Review. 97(2)1 89-202.

[24]. Gleditsch, Nils Petter, Peter Wallensteen, Mikael Eriksson, Margareta Sollenberg and Havard Strand (2002); Armed Conflict 19462001: A New Dataset. Journal of Peace Research 39(5):61 5-637.

[25]. Gourevitch, Peter (1998); we wish to inform you that tomorrow we will be killed with out families: Stories from Rwanda. New York: Picador.

[26]. Human Rights Watch (2006); "Violence beyond Borders: The Human rights Crisis in Eastern Chad". New York: Human Rights Watch, June 2006 .

[27]. Herbst, Jeffrey (1989); The Creation and Maintenance of National Boundaries in Africa..International Organisation 43 (4):673-692

[28]. Igbal, Zaryab (2006); health and Human Security: The Public Health Impact of Violent Conflict, International StudiesQuarterly, 50(3):631-649.

[29]. Jackson, Robert H. (1987); Quasi-states, Dual Regimes, and Neoclassical Theory: International Jurisprudence and the Third World. International Organization 41 (4):519-549.

[30]. Lake, David A. and Donald Rothchild (1998); Spreading Fear: The Genesis of Transnational Ethnic Conflict. In, the International Spread of Ethnic Conflict. Edited by David Lake and Donald Rothchild, Princeton, NJ: Princeton University Press.

[31]. Lischer, Sarah (2005): Dangerous Sanctuaries: Refugee Camps, Civil War, and the Dilemmas of Humanitarian Aid. Ithaca, NY: Cornell University Press.

[32]. Weiner, Myron (1992) Security, Stability, and International Migration. International Security. 17(3):91-126.s

[33]. Weiner, Myron (1978); Sons of the Soil: Migrations and Ethnic Conflict in India Princeton, NJ: Princeton University Press.

[34]. Zacher, Mark (2001); The Territorial Integrity Norm: International Boundaries and the use of Force. International Organization 55(2):215-250 